\title{
Effects of different doses of pig dung on the growth performance of Catla, Catlacatla (Hamilton, 1822)
}

\author{
Parag Mani Deka ${ }^{1}$, Krishna Kanta Tamuli ${ }^{1}$, Manas Pratim Dutta ${ }^{{ }^{*}}$, Bipul Phukan ${ }^{1}$ and \\ Sangipran Baishya ${ }^{2}$
}

${ }^{1}$ College of Fisheries, Assam Agricultural University, Assaam-782103, INDIA

${ }^{2}$ National Fisheries Development Board, North East Regional Centre, Guwahati, INDIA

*Corresponding author. E-mail: duttamax@gmail.com

Received: November 5, 2016; Revised received: September 16, 2017; Accepted: February 15, 2018

\begin{abstract}
The experiment was carried out to study the effects of different doses of pig dung on the growth rate of Catlacatla during the summer season. Rate of application of pig dung doses were $10000 \mathrm{kgha}^{-1} \mathrm{yr}^{-1}, 15000 \mathrm{kgha}^{-1} \mathrm{yr}^{-1}$, $20000 \mathrm{kgha}^{-1} \mathrm{yr}^{-1}$ and $25000 \mathrm{kgha}^{-1} \mathrm{yr}^{-1}$. The experiment was carried out in a Completely Randomized Block Design.' There were four replicates for each treatment where pig dung was applied at $10000 \mathrm{kgha}^{-1} \mathrm{yr}^{-1}\left(\mathrm{~T}_{1}\right), 15000 \mathrm{kgha}^{-1} \mathrm{yr}^{-1}$ $\left(T_{2}\right), 20000 \mathrm{kgha}^{-1} \mathrm{yr}^{-1}\left(\mathrm{~T}_{3}\right)$ and $25000 \mathrm{kgha}^{-1} \mathrm{yr}^{-1}\left(\mathrm{~T}_{4}\right)$ and control. The control pond did not receive pig dung. After 10 days of application of pig dung, Catla was stocked at the rate of 8,000 nos./ha in the fish ponds. Sampling was done at 15 days interval to study the growth rate and health status of the fishes. At the end of 3 months period, the fishes were harvested, and the performance of growth, survival and total production was recorded viz. $72.92 \pm 6.41 \mathrm{~g}$. The results of the study clearly indicated that in the indirect integration system of pig-fish farming, where fresh pig dung contains $0.61 \%$ nitrogen, $0.50 \%$ phosphate-phosphorus $\left(\mathrm{PO}_{4}-\mathrm{P}\right)$, the dung load of $20000 \mathrm{kgha}^{-1} \mathrm{yr}^{-1}$ is optimum for satisfactory growth of catla, which yield an average production of $5354.00 \mathrm{kgha}^{-1} \mathrm{yr}^{-1}$.
\end{abstract}

Keywords: Catlacatla, Completely Randomized Block Design, Growth, Pig dung

\section{INTRODUCTION}

Aquaculture has grown at an impressive rate over the past decades. The present global fish production is 158.0 million tonnes of which aquaculture contribute 66.6 million tonnes (FAO, 2014).India presently holds the second position in global fish production by registering an annual growth rate of $6.0 \%$ with total fish production of 8.67 million tonnes of which 5.29 million tonnes is from the inland fisheries sector (Anonymous, 2014).On a global basis, most cultured freshwater fishes are produced in Asia in semiintensive systems that depend on livestock wastes purposely draining in ponds. The use of livestock wastes is still needed, even when high-quality supplementary feeds are available and they are still widely used in more intensive aquaculture systems. Livestock production and processing generate by-products that may be important inputs for aquaculture. The main linkages between livestock and fish production involve the direct use of livestock wastes, as well as the recycling of manure-based nutrients which function as fertilizers to stimulate natural food webs.Integrated farming is commonly and narrowly equated with the direct use of fresh livestock manure in fish culture (Little and Edwards, 2003). For a long time now, animal manures are used in fish ponds as a source of soluble phosphorus, nitrogen and carbon to maximize the algal growth and natural food production (Ali., 1993; Njoku, 1997; Knud et al., 1998; Abbas et al., 2004). Animal manure is often used in semi-intensive systems to improve primary production of ponds and fish growth (Nwachukwu, 1997).The recycling of animal dung/ wastes in fish ponds for natural fish production is important for sustainable aquaculture and to reduce expenditure on costly feeds and fertilizers which form more than $50 \%$ of the total input cost (Dhawan and Kaur, 2002).As per Network of Aquaculture Centers in Asia (1989), the faeces of pig contain $0.6 \%$ nitrogen, $0.5 \%$ phosphorus $\left(\mathrm{P}_{2} \mathrm{O}_{5}\right)$ and $0.4 \%$ potash along with $85 \%$ moisture and $15 \%$ organic matter. This clearly indicates its ability to enhance biological productivity of water body. Time and dosage of organic manuring significantly affect the ecological processes of pond ecosystem. It encourages the organic loading and aerobic conditions, which reduces the heterotrophic activities. Manure input and fish yield are directly related with each other (Ansa and Jiya, 2002). However, indiscriminate use of these manures in fish ponds, instead of improving the pond productivity, may also lead to pollution. Therefore, it is necessary to know the actual standard dosage of pig dung, which would keep the 
physico-chemical parameters of pond water body in a favourable range required for enhancement of primary productivity of the water body and thereby, the survival and growth of fish. Considering the importance of sustainable aquaculture in the present context of rapid global climate change which eventually provides a better room for integrated fish farming to cope up with the socio-economic and ecological rationality. The present study has been taken up. The study is mainly emphasized on the effects of different doses of pig dung on plankton population, production and growth performance of Catlacatla.

\section{MATERIALS AND METHODS}

Investigations on different doses of pig dung on the growth rate of Catlacatla were carried out during the summer season.Rate of application of pig dung doses were $10000 \mathrm{kgha}^{-1} \mathrm{yr}^{-1}, 15000 \mathrm{kgha}^{-1} \mathrm{yr}^{-1}, 20000 \mathrm{kgha}^{-}$ ${ }^{1} \mathrm{yr}^{-1}$ and $25000 \mathrm{kgha}^{-1} \mathrm{yr}^{-1}$. The experiment was carried out in a Completely Randomized Block Design.There were four replicates for each treatment where pig dung was applied at $10000 \mathrm{kgha}^{-1} \mathrm{yr}^{-1}\left(\mathrm{~T}_{1}\right), 15000 \mathrm{kgha}^{-1} \mathrm{yr}^{-1}$ $\left(\mathrm{T}_{2}\right), 20000 \mathrm{kgha}^{-1} \mathrm{yr}^{-1}\left(\mathrm{~T}_{3}\right)$ and $25000 \mathrm{kgha}^{-1} \mathrm{yr}^{-1}\left(\mathrm{~T}_{4}\right)$ and control. The ponds were completely dewatered, and the bottoms were exposed to sunlight for 10 days. Then the experimental ponds were filled to the required depth and limed according to $\mathrm{pH}$ of the water to make the $\mathrm{pH}$ level optimum for the growth of fish which is 6.5-7.5. One third of the total lime required for the year was applied as the initial dose. Quick lime was used for the study. After 7 days of liming, the experimental ponds were manured with $10000 \mathrm{kgha}^{-1} \mathrm{yr}^{-1}$, $15000 \mathrm{kgha}^{-1} \mathrm{yr}^{-1}, 20000 \mathrm{kgha}^{-1} \mathrm{yr}^{-1}$ and $25000 \mathrm{kgha}^{-1} \mathrm{yr}^{-}$ ${ }^{1}$ of pig dung. One third of the total requirement of the dung was mixed with water and spread evenly on the surface of pond water as a first installment, and the rest were applied in heaps in equal installment at 15 days intervals. The control pond did not receive pig dung. Liming was done accordingly. After 10 days of application of pig dung, Catla was stocked at the rate of 8,000 nos. ha ${ }^{-1}$. Sampling was done at 15 days interval to study the growth rate and health status of the fishes. Total weight of a minimum of 10 fishes of each species of all experimental ponds was recorded. At the end of 3 months period, the fishes were harvested, and the performance of growth, survival and total production was recorded. For effective harvesting, the ponds were partially dewatered. All the data so obtained were analyzed and interpreted with different pig dung doses. Plankton analysis (ml/50l): Qualitative and quantitative analysis of plankton was carried out following Pillai (1986), Needham and Needham (1986), and Battish (1992) For counting of plankton drop count method is used. In this method, one drop of the sample is pipetted out from a calibrated pipette onto a glass slide, and the planktonic organisms are counted in strips. The total area under the cover slip represents the number of organisms present per given volume of the sample. The fortnightly estimation of plankton volume ( $\mathrm{ml} / 50 \mathrm{l})$ of water done.

\section{RESULTS}

Total plankton volume $\mathbf{m l} / \mathbf{5 0}$ liter of water: The fortnightly estimation of plankton volume $(\mathrm{ml} / 501)$ of water is presented in Table-1. Volumetric estimation of plankton biomass included both phytoplankton and zooplankton. The average value of plankton volume was $2.84 \pm 0.76 \mathrm{ml}, 3.33 \pm 0.85 \mathrm{ml}$, and $3.48 \pm 0.83 \mathrm{ml}$, $4.09 \pm 0.65 \mathrm{ml}$ in $\mathrm{T}_{1}, \mathrm{~T}_{2}, \mathrm{~T}_{3}$, and $\mathrm{T}_{4}$ respectively. In $\mathrm{T}_{2}$ higher volume of plankton was observed than $T_{1}$, the value ranges from $2.33 \mathrm{ml}$ to $4.54 \mathrm{ml} / 501$. In this treatment, the plankton volume showed an increasing trend from $1^{\text {st }}$ to $13^{\text {th }}$ sampling day. In $\mathrm{T}_{3}$ plankton volume ranged from 2.53 to $3.77 \mathrm{ml}$. The $\mathrm{T}_{4}$ showed the higher volume of plankton among all the treatment, the value steadily increased, to $5.40 \mathrm{ml}$ on $13^{\text {th }}$ sampling day, where as in control, plankton volume ranged from 0.24 to $0.43 \mathrm{ml} / 50$ lduring the experimental period.

Qualitative analysis of plankton: The dominant groups of plankton identified during the 3 months periodsareare listed below:

\section{Phytoplankton}

Chlorophyceae: Euglena, Spirogyra, Chlorella, Volvox, Pediastrum, Chlamydomonus; Selenestrum, Zygnema, Microsporodium, UIothrix, and Ankistrodesmus.

Cyanophycea: Anabaenaa ,Nostoc, Spirulina, Merismopedia, and Microcystis.

Desmidiaceae: Closterum, Genicularia, andNetrium, Bacillariophyceae:Fragilaria, Nitzschia, Tabellaria, Synedra, and Cymbella.

\section{Zooplankton}

Rotifers: Brachionus ,AsplanchaKeratella, Filinia, , Synchaeta, Polyarthra, andRotaria

Copepods: Cyclops, Nauplius, andDiaptomus,

Cladocerans: Moina, Daphnia, Bosmina, Ceriodephnia, andSimocephalus

Protozoans:Ceratium, Peridinium, Eudorina and Difflugia.

Growth performance of the fishes in the treated and control ponds: The results of fish performance in indirect integrated fish-pig farming system at the rate of dung doses 10,000 $\mathrm{kgha}^{-1} \mathrm{yr}^{-1} 15,000 \mathrm{kgha}^{-1} \mathrm{yr}^{-1}$, 20,000 $\mathrm{kgha}^{-1} \mathrm{yr}^{-1}, 25,000 \mathrm{kgha}^{-1} \mathrm{yr}^{-1}$ are presented in are presented in Table -1 . In all the treatments, the survivality of catla was found to be the best $(75 \%)$, the highest survivality was observed in $\mathrm{T}_{1}(75 \%)$ followed by $\mathrm{T}_{2}(72.81 \%) \mathrm{T}_{3}(71 \%)$ and $\mathrm{T}_{4}(61.87 \%)$. The fish also showed better survivality in control (74.06\%). Catla being the surface feeder, the highest survivality may be due to the appropriate production of plankton in the treated ponds due to the addition of pig manure. The highest fish production was achieved in $T_{3}$ (5354.00 $\left.\mathrm{kgha}^{-1} \mathrm{yr}^{-1}\right)$ followed by $\mathrm{T}_{2}\left(5002.40 \mathrm{kgha}^{-1} \mathrm{yr}^{-}\right.$ 
Parag Mani Deka et al. / J. Appl. \& Nat. Sci. 10 (1): 425 - 429 (2018)

Table 1. Variation of plankton volume $\mathrm{ml} / 50$ literin pig dung treated and control ponds during the period of study.

\begin{tabular}{|c|c|c|c|c|c|}
\hline \multirow{2}{*}{$\begin{array}{l}\text { Sampling Days } \\
\text { (Fortnightly intervals) }\end{array}$} & \multicolumn{4}{|c|}{ Treatment ponds } & \multirow[b]{2}{*}{$\mathbf{C}$} \\
\hline & $T_{1}$ & $\mathbf{T}_{2}$ & $\mathbf{T}_{3}$ & $\mathbf{T}_{4}$ & \\
\hline 1 & 2.15 & 2.33 & 2.60 & 3.70 & 0.43 \\
\hline 2 & 1.65 & 2.35 & 2.53 & 3.73 & 0.28 \\
\hline 3 & 3.00 & 3.65 & 3.70 & 3.90 & 0.25 \\
\hline 4 & 3.52 & 3.62 & 3.68 & 3.92 & 0.38 \\
\hline 5 & 3.34 & 3.48 & 3.56 & 4.82 & 0.28 \\
\hline 6 & 3.38 & 4.54 & 4.77 & 5.40 & 0.24 \\
\hline Average \pm SD & $2.84 \pm 0.76$ & $3.33 \pm 0.85$ & $3.48 \pm 0.83$ & $4.09 \pm 0.65$ & $0.31 \pm 0.08$ \\
\hline
\end{tabular}

Table 2. Body weight gain and production of Catla in pig dung treated and control ponds.

\begin{tabular}{|c|c|c|c|c|c|c|}
\hline \multirow[t]{2}{*}{ Sl. No } & \multirow[t]{2}{*}{ Treatment } & \multirow[t]{2}{*}{ Species } & \multicolumn{3}{|c|}{ Body weight gain $(\mathrm{g})$} & \multirow{2}{*}{$\begin{array}{c}\text { Production } \\
\text { Gross }\left(\mathrm{Kg} \mathrm{ha}^{-1} \mathrm{yr}^{-1}\right)\end{array}$} \\
\hline & & & Initial & Final & Body weight gain (g) & \\
\hline 1 & T1 & Catla & 55.00 & 244.20 & 189.20 & 4951.20 \\
\hline 2 & $\mathrm{~T} 2$ & Catla & 55.00 & 253.10 & 198.10 & 5002.40 \\
\hline 3 & $\mathrm{~T} 3$ & Catla & 55.00 & 280.20 & 225.20 & 5354.00 \\
\hline 4 & $\mathrm{~T} 4$ & Catla & 55.00 & 239.00 & 184.00 & 4014.00 \\
\hline 5 & $\mathrm{~T} 5$ & Catla & 55.00 & 80.00 & 25.00 & 1330.40 \\
\hline
\end{tabular}

Values are averages of four replications

Table 3. Plankton volume and comparison of mean growth $( \pm \mathrm{SE})$ and survivality of Catla in the present study.

\begin{tabular}{|c|c|c|c|}
\hline \multirow{3}{*}{ Treatment } & \multirow{3}{*}{ Plankton volume (ml/50l) } & \multicolumn{2}{|c|}{ Fish species } \\
\hline & & \multicolumn{2}{|c|}{ Catla } \\
\hline & & Mean growth & Survival \\
\hline Control & $0.41 \pm 0.14^{\mathrm{a}}$ & $72.92 \pm 2.62^{\mathrm{a}}$ & $74.06\left(59.38 \pm 0.95^{b}\right.$ \\
\hline $\mathrm{T}_{1}$ & $2.59 \pm 0.52^{b}$ & $174.87 \pm 24.97^{\mathrm{b}}$ & $75(60.00) \pm 1.12^{b}$ \\
\hline $\mathrm{T}_{2}$ & $3.03 \pm 0.24^{b}$ & $179.47 \pm 25.16^{\mathrm{b}}$ & $72.81(57.83) \pm 1.31^{\mathrm{b}}$ \\
\hline $\mathrm{T}_{3}$ & $3.39 \pm 0.21^{\mathrm{c}}$ & $193.22 \pm 28.93^{\mathrm{c}}$ & $71(57.42) \pm 1.62^{\mathrm{b}}$ \\
\hline $\mathrm{T}_{4}$ & $3.44 \pm 0.26^{\mathrm{c}}$ & $168.00 \pm 24.04^{\mathrm{b}}$ & $61.87(51.87) \pm 1.54^{\circ}$ \\
\hline $\operatorname{SEm}( \pm)$ & 0.19 & 14.17 & 1.02 \\
\hline
\end{tabular}

Values are mean $( \pm \mathrm{SE})$, values in different superscript were significantly different $(\mathrm{p}<0.05)$, and Values in parenthesis are angular value.

1) $\mathrm{T}_{1}\left(4951.20 \mathrm{kgha}^{-1} \mathrm{yr}^{-1}\right) \mathrm{T}_{4}\left(4014.40 \mathrm{kgha}^{-1} \mathrm{yr}^{-1}\right)$ and in the control $\left(1330.40 \mathrm{kgha}^{-1} \mathrm{yr}^{-1}\right)$. Though the survival percentage was higher in $\mathrm{T}_{1}$, control and $\mathrm{T}_{2}$ respectively, the growth of fishes was not found satisfactory. In $\mathrm{T}_{3}$ all the species of fishes showed better weight gain. It was observed in the present study that though the survival percent was found to be best in $T_{1}$, total yield was found to be low. The highest production was observed in $T_{3}$, with pig dung dose at the rate of 20,000 $\mathrm{kg} \mathrm{ha}^{-1} \mathrm{yr}^{-1}$. In $\mathrm{T}_{2}$ and $\mathrm{T}_{3}$ growth and survival of catlawere found to be good, which may be attributed to the increase in the amount of pig dung. Increased dung load resulted in the improved nutritional status of soil and water and plankton production. However further increased in organic load was not observed to augment growth of fishes in $\mathrm{T}_{4}$, due to the imbalance of production and consumption of primary producers, coupled with deterioration of water quality parameters, mainly morning DO level $(2.08 \pm 0.24)$ and accelerate the production of ammonia $\left(0.88 \pm 0.22 \mathrm{mgl}^{-1}\right)$.

\section{DISCUSSION}

The success of fish culture operation depends on the favourable aquatic environment for the production of desirable fish food organisms.Water and soil of an aquatic system play a conducive role in the growth of fish and water being the prime requisite to support aquatic life, its physico-chemical properties are responsible for maintaining the aquatic environment and makes it favourable for aquatic organisms. Pond fertilization is a management protocol to enhance biological productivity using both organic manure and inorganic chemical fertilizers. It is therefore essential to have proper knowledge of the growth of fish food organisms and thereby pond productivity and fish growth. The use of pig manure as a source of nutrients for fish production makes good economic and ecological sense. A uniform production of plankton has also been reported from ponds recycled with pig dung (FAO, 2014). Kalita et. al. (2012) stated that different types of algal species are found responsible for blooms in ponds treated with pig excreta. Increases in pig production in China are attributed not only to their value for meat production but because pigs are viewed in China as a "costless fertilizer factory moving on hooves" (FAO, 1977). Manures are not as nutrient-rich as inorganic fertilizers, but they efficiently promote robust algae blooms (Conte,2000). The nutritional value of pig manures to phytoplankton is variable. They contain not only the primary nutrients nitrogen, phosphorus and potash, but also supplies of secondary nutrients required by plants (Chastain et. al. 2003) and missing 
from many inorganic fertilizers.

In the present study, the treated ponds $T_{1}, T_{2} T_{3}$ and $T_{4}$ received pig dung. The manure loads went on increasing from $T_{1}$ to $T_{4}$ being $10,000 \mathrm{kgha}^{-1} \mathrm{yr}^{-1}\left(\mathrm{~T}_{1}\right), 15000$

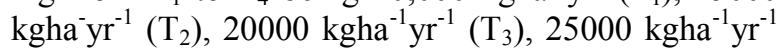
$\left(\mathrm{T}_{4}\right)$. Thus, nutrient status and total alkalinity also increased in these ponds accordingly. The values of total alkalinity were $124.02 \pm 10.1, \quad 125.97 \pm 11.9$, $127.07 \pm 12.5$ and $129.81 \pm 14$ for $\mathrm{T}_{1}, \mathrm{~T}_{2}, \mathrm{~T}_{3}$ and $\mathrm{T}_{4}$ respectively.

The pattern of the constant increasing trend of plankton in the treated ponds during the study period confirmed the role of water temperature and photoperiod (Tavares et al., 2010), $\mathrm{pH}$ and total alkalinity (Prithwiraj et al., 2008). $\mathrm{NO}_{3}-\mathrm{N}$ and $\mathrm{PO}_{4}-\mathrm{P}$-status of pond water (Freid et al. 2003) and DO (Gormaz et al., 2014) in production profile and total plankton production. Diana et al.(2012) reported the volume of plankton in the range from 1.2 to $7 \mathrm{ml} / 501$ in a pond where pigs were stocked at the rate of 40 no.ha ${ }^{-1}$. At the same density of pig, Sun et al. (2010) estimated plankton production in the range between $0.5 \mathrm{ml}$ and $2 \mathrm{ml} / 501$. According to Kumar et al. (2012), plankton value should not be below $2 \mathrm{ml} / 50$ for carp culture ponds. The biological productivity of any aquatic body is generally judged through the qualitative and quantitative estimation of plankton, which forms the natural food of fish (Naga, 2002) Animal wastes lead to increased biological productivity of ponds through various pathways, which result in an increase in fish production The plankton production was significantly higher in ponds receiving pig dung than in control ponds. This may be due to a high level of water-soluble phosphates in the pig dung (Naga, 2002).

In the present study average volume of total plankton was $2.84 \pm 0.763 .33 \pm 0.85,3.48 \pm 0.83,4.09 \pm 0.65 \mathrm{ml}^{\circ} 501^{-}$

${ }^{1}$ in $\mathrm{T}_{1}, \mathrm{~T}_{2}, \mathrm{~T}_{3}, \mathrm{~T}_{4}$ treatment respectively indicating high productivity in $\mathrm{T}_{3}$ and $\mathrm{T}_{4}$. In the integrated pig fish farming system (indirect) developed in the present study, the productivity level achieved in the $\mathrm{T}_{3}$ was found comparable to most of the results obtained so far in India and abroad. Dhawan and Kaur (2002) conducted a pig-fish farming experiment in 0.1 ha pond with pig and fish density at the rate of 40 and $8500 \mathrm{ha}^{-1}$ pig and fish respectively. The productivity was $6791.70 \mathrm{~kg}^{-1} \mathrm{ha}^{-1} \mathrm{yr}^{-1}$. Catla showed the survival rate of $71.35 \%$, whereas, in the present experiment with a similar density of fish, the highest productivity to the tune of $5354.00 \mathrm{kgha}^{-1} \mathrm{yr}^{-1}$ was observed in $\mathrm{T}_{3}$ with the pig dung loadat $20000 \mathrm{kgha}^{-1} \mathrm{yr}^{-1}$. The survivality rate observed in catla was $71 \%$.Similar results were also achieved by many workers (Mlejnkova et al., 2012). Such performance of the surface feeder is attributable to the abundance of fish food organisms at the surface layer of water in pig-fish farming system. In the present study $40 \%$ of the total stocking density comprised with the surface feeder (catla).Tabindaet. al.(2009) suggested the stocking density of more number of filter feeding fishes in the manure loaded pond. The main reason of the best production in $T_{3}$ may be attributed to the abundance of fish food organisms such as phytoplankton and zooplankton, benthic insects, worms, larvae and a great number of microorganisms in, where physico-chemical water parameters and nutrient level were also in favourable range. Besides consuming the natural food organisms, the fish in the treated pond were also observed to feed directly on pig excreta, exhibiting their coprophagus nature corroborating the findings of Le mare (1952), where he observed direct feeding of pig-dung by carps. The probable reason for low fish production in $\mathrm{T}_{1}$ was less production of fish food organism which is also partially applicable in the case of $T_{2}$. In $T_{4}$ due to very high organic load, water quality started to deteriorate particularly low morning DO and high ammonia production which correlates with the findings of Boyd (2006). Fishes were constantly under stress condition which is reflected in overall low survivality low individual growth rate and final production profile in all the replications of $\mathrm{T}_{4}$

\section{Conclusion}

To study the effects of different dosages of pig dung on the growth performance of catla, an experiment was carried out with the key objectives of developing sustainable aquaculture by applying pig dung in the ponds. The foremost part of the research work was to optimize the dosage of pig dung for improving the biological productivity of pond ecosystem there by maximizing the productivity.In the present study, among phytoplankton, cyanophyceae was the dominant group followed by chlorophyceae, but the diversity of chlorophyceae was observed more than cynophyceae and among zooplankton, Rotiferawas, the dominant group. The results of the study clearly indicate that in the indirect integration system of pig-fish farming, where fresh pig dung contains $0.61 \%$ nitrogen, $0.50 \%$ phosphatephosphorus $\left(\mathrm{PO}_{4}-\mathrm{P}\right)$, the dung load of $20000 \mathrm{kgha}^{-1} \mathrm{yr}^{-1}$ is optimum for satisfactory growth of catla, which yield an average production of $5354.00 \mathrm{kgha}^{-1} \mathrm{yr}^{-1}$. The above study also reveals that pigdung even at a higher dose did not adversely affect the physico-chemical parameters of water. The pond productivity was significantly higher in manured ponds than control ponds. The growth of $C$. catla in manured ponds was better than in control ponds.

\section{REFERENCES}

Abbas, S., Ahmed, I. and Akhtar, P. (2004). Effect of different levels of poultry droppings on the growth performance of major carps. Pak. Vet. J., 24 (3): 139-143.

Ali, S. S. (1993). An Introduction to Freshwater Fishery Biology. I ${ }^{\text {st }}$ Edn. University Grant Commission, Islamabad. 246.

Anonymous (2014). Annual report of Department of Fisher- 
ies, Assam

Ansa, E. and Jiya, J. (2002). Effects of pig manure on the growth rate of Tilapia under intregrated pig cum fish culture J. Aqua. Sci., 17(2): 85-87.

Battish, S. K. S. (1992). Freshwater zooplankton of India. $1{ }^{\text {st }}$ Edn., Oxford \& IBH Publ. Co. Pvt. Ltd, New Delhi, India.

Boyd, C.E. (2006) Management of Bottom Soil Condition and Pond Water and Effluent Quality. In: Lim, C.E. and Webster, C.D., Eds., Tilapia Biology, Culture, and Nutrition, Food Products Press, New York, 449-467.

Chastain, J.P., Camberato, J.J., Albrecht, J.E. and Adams, J. (2003) Swine Manure Production and Nutrient Content. Chapter 3a. In: Confined Animal Manure Managers Certification Program Manual B Swine Version 3, Clemson University Cooperative Extension Service

Conte, F.S. (2000) Pond Fertilisation: Initiating an Algal Bloom. Western Regional Aquaculture Center, WRAC Publication No. 104 02-2000, Seattle.

Diana, J. (2012) Some Principles of Pond Fertilization for Nile Tilapia Using Organic and Inorganic Inputs. In: Mischke, C.C., Ed., Aquaculture Pond Fertilization: Impacts of Nutrient Input on Production, 1st Edition, John Wiley and Sons, Inc., Hoboken.

Dhawan , A. and Kaur, S. (2002). Effect of pig dung on growth and reproductive potential of Cyprinuscarpio. Ind. Jour.fish. 49(1):103-106.

FAO (United Nations Food and Agriculture Organization) (1977) China: Recycling or Organic Wastes in Agriculture.Report of the FAO Study Tour to the People's Republic of China, 28 April-24 May 1977. FAO Soils Bulletin 40.

FAO (2014). Environment and natural resources series on Organic Aquaculture - Current Status and Future prospects. 4: 13 .

Freid, S., Mackie, B. and Nothwehr, N. (2003). Nitrate and phosphate levels positively affect the growth of algae species found in Perry Pond. Tillers, 4, 21-24.

Gormaz, J.G., Fry, J.P., Erazo, M., and Love, D.C. (2014) Public Health Perspectives on Aquaculture. Current Environmental Health Reports.

Kalita, K., Tamuli, K. K., Baishya, S. and Phukan, B. (2012). Dynamics of Algal Bloom in Freshwater Pond Treated with Pig Excreta and Its Control Measures. Env. Ecol., 30 (3A): 749-751.

Knud-Hansen, C. F., Batterson, T. R. and McNabb, C.D. (1998). The role of chicken manure in production of Nile tilapia, Oreochromis niloticus. Aquacult. Fish.
Manag, 24: 483-493.

Kumar, J. Y., Chari, M. S. and Vardia H. K. (2012). Effect of integrated fish-duck farming on growth performance and economic efficiency of Indian major carps. Live. Res. Rural Dev., 24(12):15-19.

Le Mare, D. W. (1952). Pig rearing, fish-farming and vegetable growing. Malayan Agric. J. 35(3): 156-166.

Little, D. C. and Edwards, P. (2003). Integrated livestockfish farming systems, Inland Water Resources and Aquaculture Service Animal Production Service, Food and Agriculture Organization of the United Nations, Rome.

Mlejnkova, H., Sovova, K., 2012. Impact of fish pond manuring on microbial water quality. Acta Univ. Agric. Silvic. Mendel. Brun. LX (3), 117-124.

NACA (1989). Network of Aquaculture Centers in Asia. Manual on Introduction of chinese integrated fish farming and some major models. China, pp 7.

Naga (2002). The ICLARM Quarterly (Vol. 25, No. 1) January-March.

Needham, G. J. and Needhum, P. R. (1986). A guide to fresh water biology 5 th edn., Holdon Day Inc. San Francisco.

Njoku, D. C. (1997). Effect of different manure levels on fish growth, mortality and yield in a horizontallyintegrated fish-cum-poultry farming system in Nigeria. Aqua. Res., (28): 651-660.

Nwachukwu, V. N. (1997). Proceeding on Tilapia nutrition through substrate enhancement in ponds: a cheap, sustainable, and environmentally friendly feeding method.International Symposium onTilapia in Aquaculture, Coronado Springs Resort Walt Disney World, Orlando, FL, USA, 1: 50-55.

Pillai, N. K. (1986). Introduction to Planktonology. Himalaya Publ. House, Bombay, India.

Prithwiraj, J., Sudip, B., Chitta, R.N., 2008. Fish production, water quality and bacteriological parameters of Koi carp ponds under live-food and manure based management regimes. Zool. Res. 29 (2), 165-173.

Sun, W., Dong, S., Zhao, X., Jie, Z., Zhang, H. and Zhang, L. (2010). Effects of zooplankton refuge on the growth of tilapia (Oreochromis niloticus) and plankton dynamics in pond. Aquacult. Int., 18:647-655

Tabinda, A. B and Ayub, M. (2009). Effect of high phosphate fertilization rate on pond phosphate concentrations, chlorophyll a, and fish growth in carp polyculture. Aquacult. Int., 9: 9243-9249.

Tavares, L. H. S., Millan, R. N. and Santeiro, R. M. (2010). Characterization of a plankton community in a fish farm. Acta Limnologica Brasiliensia, 22(1): 60-69 